\title{
Spatial and Temporal Distribution of Bromide as a Nitrate Tracer in Deficit, Drip-irrigated Wine Grape Vineyards
}

\author{
Joan R. Davenport ${ }^{1,3}$ and Robert G. Stevens ${ }^{1}$ \\ Washington State University Irrigated Agriculture Research and Extension \\ Center, 24106 N. Bunn Road, Prosser, WA 99350
}

\author{
Kelly M. Whitley ${ }^{2}$ \\ CH2MHill Plateau Remediation Company, P.O. Box 1600, Richland, WA \\ 99352
}

\section{Tanya Winkler ${ }^{1}$ \\ Washington State University Irrigated Agriculture Research and Extension Center, 24106 N. Bunn Road, Prosser, WA 99350}

Additional index words. bromide, nitrate, volumetric soil water, plant available water, regulated deficit irrigation

\begin{abstract}
Understanding water and nutrient movement in arid climate-regulated deficit, drip-irrigated vineyards is imperative for understanding grape vine canopy management. However, little research has been conducted in these environments to aid in the understanding of where the vine accesses nutrients and/or soil water and how that translates into soil and/or plant tissue sampling approaches. We used bromide (Br) as a tracer to study nitrate movement in soils as well as into grape leaves in two 'Merlot' vineyards in central Washington State. Bromide movement closely followed water movement. Although $\mathrm{Br}$ was detectable in grape petioles, it was not detectable in leaf blades, likely as a result of a dilution factor related to the amount of tissue. Relationships between soil $\mathrm{Br}$ and soil moisture as well as petiole and soil $\mathrm{Br}$ concentrations suggests that soil sampling for nitrate should be taken from a diagonal position between the vine and the emitter, between 20 and $60 \mathrm{~cm}$ from the drip line. This is consistent with the recommendation for soil moisture sampling in a published companion study.
\end{abstract}

Water movement in regulated deficit irrigated wine grape vineyards in the inland Pacific Northwest has been shown to be restricted to a fairly small zone and often soil moisture status is very low (Davenport et al., 2008). Because plant nutrient availability and, in the case of $\mathrm{NO}_{3}-\mathrm{N}$, movement are closely related to soil moisture distribution, the results of soil moisture studies suggest that mobile anionic plant nutrient distribution may be found in specific zones in the soil.

Bromide is routinely used as a tracer for mobile anionic plant nutrient movement (e.g., nitrate, chloride) in the soil (Fisher and Healy, 2008; Green et al., 2005; Izadi et al., 1993; Logsdon, 2007; Schuh et al., 1997; Seo et al.,

\footnotetext{
Received for publication 18 Oct. 2010. Accepted for publication 16 Nov. 2010.

This research was funded by grants from the Northwest Center for Small Fruit Research with supplemental funding from the Washington State University Agriculture Research Center.

We thank those diligent diggers, Jaimi Marden, Tyler Phillips, Kelsey Myers, and Joanna Pierce, and Drs Troy Peters and Bill Pan for their review comments.

${ }^{1}$ Professor, Soil Scientist, Emeritus Extension Soil Scientist, and Agric. Res. Tech. II.

${ }^{2}$ Scientist.

${ }^{3}$ To whom reprint requests should be addressed; e-mail jdavenp@wsu.edu.
}

2005) as well as in studies looking for offtarget movement affecting groundwater in delicate ecosystems (Elçi and Molz, 2009; Woodward et al., 2009). In addition, it has successfully been used as a tracer of nitrogen $(\mathrm{N})$ movement in both soils and plants (McLeod et al., 1998; Patra and Rego, 1995). Although most of the work using $\mathrm{Br}$ as a tracer in agricultural systems has focused on annual crops such as corn, wheat, potato, and cotton (Izadi et al., 1993; Kessavalou et al., 1996; Ottman and Pope, 2000; Silvertooth et al., 1992), work in the perennial forage crops (Blumenthal et al., 1999; Magarian et al., 1998; Schnabel et al., 1995) and in the citrus trees (Harrison et al., 1999) have shown $\mathrm{Br}$ to be a valid tracer of movement in many soil and plant systems. Magarian et al. (1998) used a combination of ${ }^{15} \mathrm{~N}$-labeled ammonium nitrate and $\mathrm{Br}$ as $\mathrm{KBr}$ to trace $\mathrm{N}$ movement in alfalfa. They found that $\mathrm{NO}_{3}$ and $\mathrm{Br}$ uptake was consistent across numerous alfalfa germplasms, suggesting that $\mathrm{Br}$ is a cost-effective alternative to ${ }^{15} \mathrm{~N}$-labeled compounds to trace $\mathrm{N}$ use in plants.

Bromide has also been successfully demonstrated to be a useful tracer in studies of spatial and temporal distribution of nutrients in soils (Kohne and Gerke, 2005). Kessavalou et al. (1996) used $\mathrm{Br}$ and ${ }^{15} \mathrm{~N}$ in a corn field to trace $\mathrm{NO}_{3}-\mathrm{N}$ leaching to groundwater and found that $\mathrm{Br}$ and the ${ }^{15} \mathrm{~N}$ followed similar patterns in non-irrigated cropping systems. Schuh et al. (1997) found similar results with $\mathrm{Br}$ and nonlabeled $\mathrm{NO}_{3}-\mathrm{N}$

Soil sampling for nutrients, and $\mathrm{N}$ in particular, is challenging in perennial cropping systems. Recent research has shown very low soil moisture levels in deficit drip-irrigated wine grape vineyards in the inland Pacific Northwest with significant variation within the season (Davenport et al., 2008). This suggests that, rather than random soil sample collection, there may be a specific location in the soil in relation to vine and drip emitter location to best reflect vine root nitrate extraction.

We used $\mathrm{Br}$ as a tracer for nitrate movement in regulated deficit drip-irrigated vineyards in the inland Pacific Northwest. Our hypothesis was that $\mathrm{Br}$ movement would closely follow water distribution patterns in drip-irrigated vineyards (Davenport et al., 2008). Our objective was to develop an understanding of the distribution of $\mathrm{Br}$ as a surrogate for $\mathrm{NO}_{3}-\mathrm{N}$ and other mobile anions within the wetted root zone. Based on this understanding, we strove to determine the most representative location for soil sample collection for assessing the availability of mobile anionic nutrients when dripapplied in regulated deficit-irrigated vineyards.

\section{Materials and Methods}

The sites for this research were two dripirrigated winegrape (Vitis vinifera $\mathrm{L}$.) vineyards near Prosser, WA (between lat. $46^{\circ} 15^{\prime}$ and $46^{\circ} 18^{\prime}$ and long. $119^{\circ} 32^{\prime}$ and $\left.119^{\circ} 48^{\prime}\right)$. Both were planted with own-rooted 'Merlot' and managed from inception using regulated deficit drip irrigation (Evans, 1993, Evans et al., 1993). Vines were spaced with $1.83 \mathrm{~m}$ between plants and $3.05 \mathrm{~m}$ between rows. In each vineyard, individual drip emitters within a 15 - to $20-\mathrm{cm}$ distance from a vine trunk were identified. As per Rolston et al. (1991), each emitter was considered fixed in space for the duration of the single season of sampling. A half radial pattern was marked around each emitter spanning $60 \mathrm{~cm}$ both left and right of the emitter in the row and to a distance of $60 \mathrm{~cm}$ into the interrow (Fig. 1). Row orientation in both vineyards was north-south. All emitters were rated at $2 \mathrm{~L} \cdot \mathrm{h}^{-1}$. Additional information on year of planting, soil series, texture, annual irrigation applications, and precipitation during the time of this study is available in Davenport et al. (2008).

Six replicates (emitters within 15 to $20 \mathrm{~cm}$ from vine trunk) were treated in one row in each vineyard with a minimum of three vines between sample vines. The $\mathrm{Br}$ application was made just before veraison (670 degreedays, base $10{ }^{\circ} \mathrm{C}$; Keller et al., 2004) to be consistent with standard $\mathrm{N}$ application timing for winegrape vineyards in this growing area (R. Smithyman, personal communication). Midway through the 670 degree-day irrigation event, $200 \mathrm{~mL}$ of a $\mathrm{KBr}$ solution $(225$ $\mathrm{mg} \cdot \mathrm{L}^{-1}$ ) was applied by placing the solution in a small cup with a hole, sized to drip at the same rate as the emitter, hung directly under the emitter (Waters et al., 2005) and left on for the duration of the irrigation event. Soil 
samples were collected from 16 points in a radial pattern (Davenport et al., 2008) to four different depths ( 0 to 15,15 to 30,30 to 45 , and 45 to $60 \mathrm{~cm}$ ) using a $2.45-\mathrm{cm}$ ID soil probe around the treated vines (Fig. 1).

Sample collections were made 1 and $2 \mathrm{~d}$ after the 670 degree-day irrigation, $2 \mathrm{~d}$ after the next irrigation, $2 \mathrm{~d}$ after the last irrigation of the season as well as in March after winter seasonal precipitation accumulation (days after application $1,2,7$ or 6,76 , and 225 or 230 for Vineyards 1 and 2, respectively) to reflect soil conditions from midseason through the next spring. Soil samples (one per depth location vine) were placed in cans, returned to the laboratory, weighed, and dried for 24 to $30 \mathrm{~h}$ at $105^{\circ} \mathrm{C}$ to determine gravimetric soil moisture. Soils were then water extracted (1:1 soil:deionized water, shaken for $30 \mathrm{~min}$ ) and analyzed colorimetrically for $\mathrm{Br}$ (Stenger and Kolthoff, 1935) on an EnviroFlow 3000 Auto Analyzer (O-I Analytlical, College Station, TX). After each soil sample was collected, soil from the vineyard site was placed in each sampling hole and each sampling hole was marked to prevent sampling the same site and to allow water and $\mathrm{Br}$ movement throughout the profile. Additional samples at each location were taken immediately adjacent to the previous sampling location.

Leaf tissue samples were collected from each treated vine in each vineyard on Day 2, Day 7 or 6, and again the next spring at bloom (320 and $325 \mathrm{~d}$ after application). Leaf samples were not collected at the other two soil sampling times as a result of lack of leaf tissue on the plants. A total of 10 leaves from the fifth mature leaf position was collected from each study vine (east and west sides of the canopy) at each sampling time and separated into petiole and blade components. Leaf petioles and blades were dried at $60{ }^{\circ} \mathrm{C}$ for $24 \mathrm{~h}$, ground, extracted with deionized water (1:100 w:v), and analyzed for $\mathrm{Br}$ as described previously.

The soil bromide data were analyzed using Proc GLM and relationships between soil and tissue with PROC REG with PC SAS (SAS Institute, Cary, NC).

Soil sample Br concentration from each of the six vines was averaged at each vineyard, sample time, depth, and position. The average values were then normalized for spatial analysis and representation. The $\mathrm{Br}$ concentration for each vineyard was divided by the highest concentration (recovery) to normalize the data by site. The same normalization approach was used for soil moisture data (Davenport et al., 2008). The normalized data were extrapolated across the surface of the sampling area by inverse distance weighting with ArcGIS Version 9.1 (ESRI, Redlands, CA) using a power of 4 and a $n-1$ point search radius.

\section{Results and Discussion}

Soil bromide concentration and distribution. Soil Br concentration varied by vineyard, sampling time, distance from the emitter, and the interactive factors except vineyard by sampling time (Table 1). Vineyard differences likely are a combination of irrigation

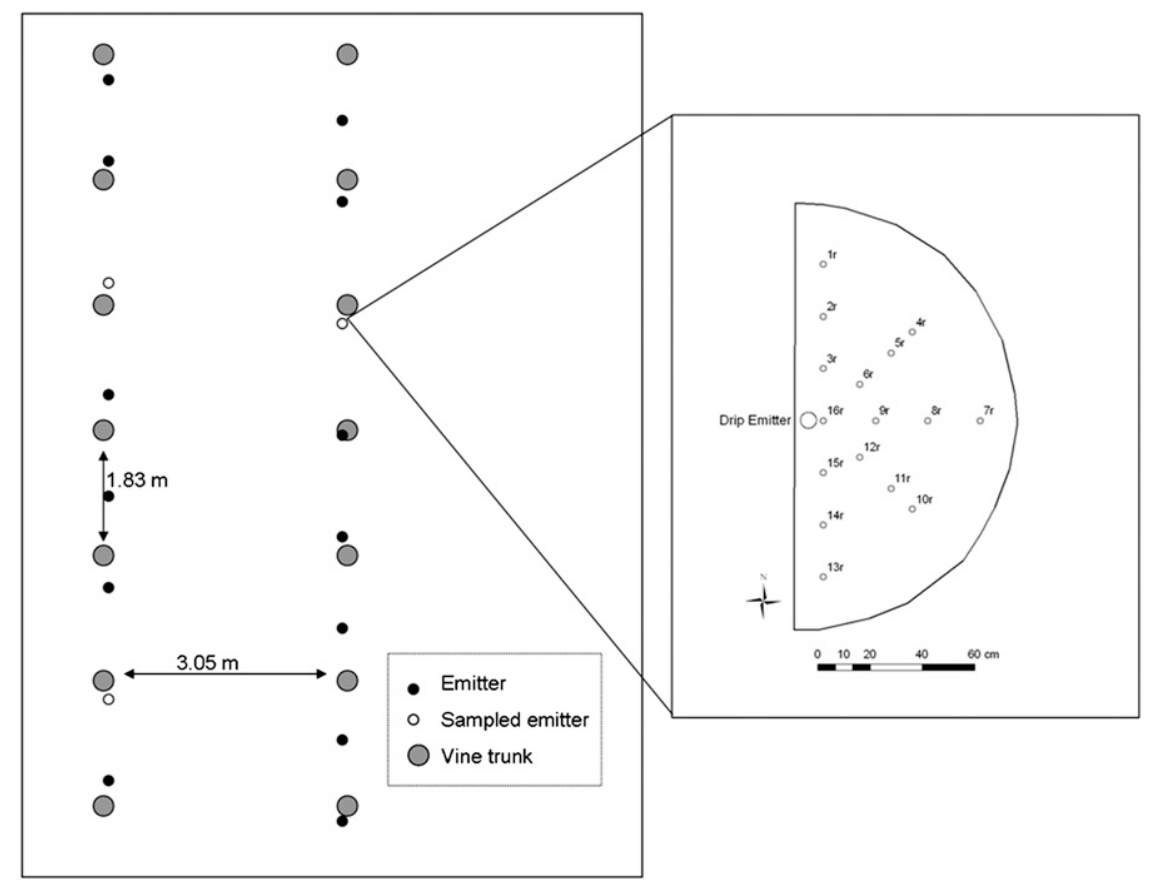

Fig. 1. Diagram of the sampling scheme (not entire vineyard block) for soil sampling in vineyard. Sampling points, location of drip emitter, and half circle radius for interpolating the data for a study of soil bromide distribution in regulated deficit-irrigated wine grape vineyards in the Yakima Valley, WA.

Table 1. Average soil bromide ( $\mathrm{Br})$ concentration for main factors and level of significance for main and interactive factors in a study using $\mathrm{Br}$ as a nutrient tracer in regulated deficit irrigated vineyards in the Yakima Valley, WA. ${ }^{2}$

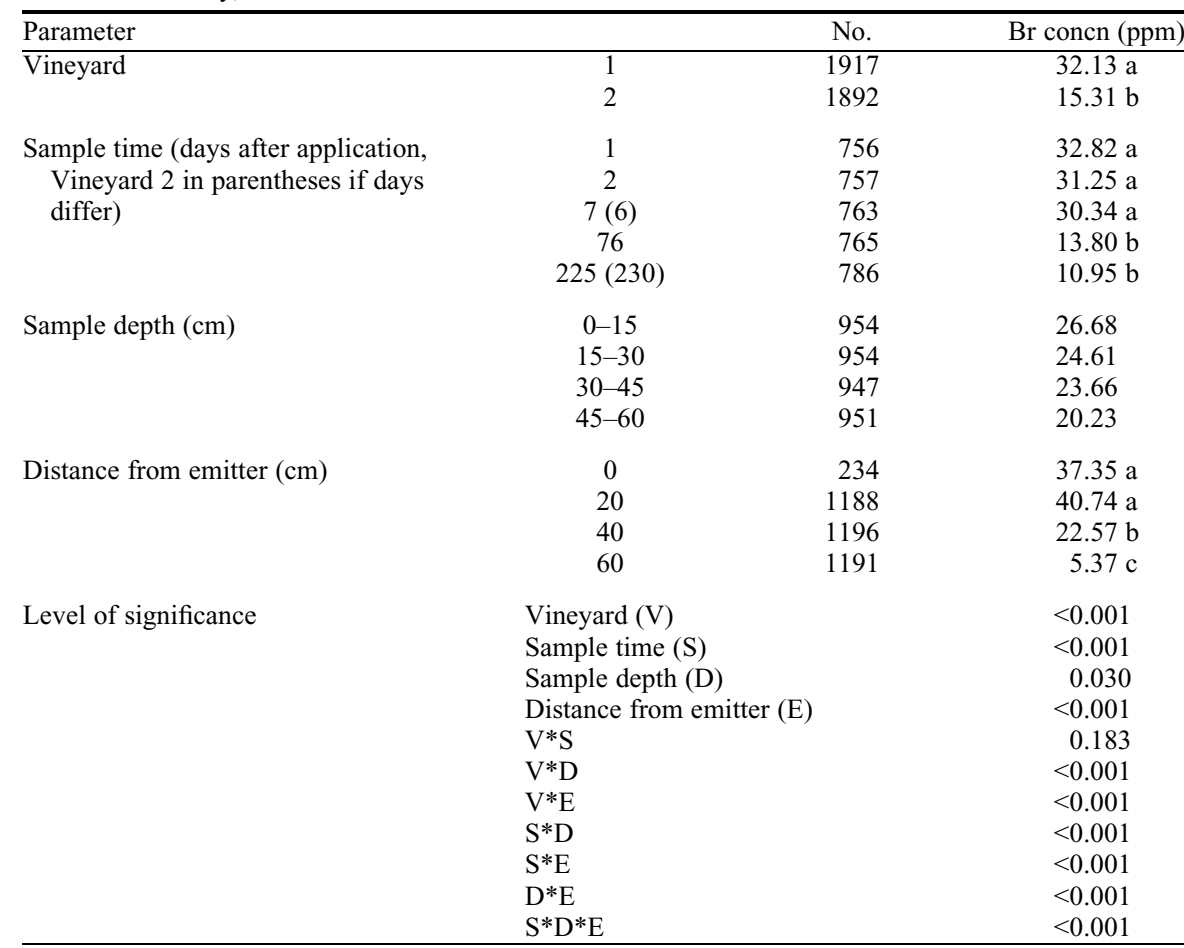

${ }^{\mathrm{z} \text { Means separation by least significant difference }(\alpha=0.05) \text { shown as different letter values for each }}$ parameter.

management, row side sampled with respect to water flow patterns, and plant size (both canopy and roots) effects on soil water use. Vineyard 1 had higher average soil $\mathrm{Br}$ concentration than Vineyard 2 (Table 1). Soil Br concentration was highest during the first three sampling intervals and lower during the second two. Distance from the emitter resulted in declining soil $\mathrm{Br}$ concentration from 20 to 40 to $60 \mathrm{~cm}$ away from the emitter (Table 1).

There were significant relationships between the distance from the emitter and soil 
$\mathrm{Br}$ concentration at each sampling time in each vineyard (Table 2). However, depth was only significantly related to soil $\mathrm{Br}$ concentration at the first sampling date at Vineyard 2, whereas there were significant relationships between soil $\mathrm{Br}$ and depth for all sampling times except $76 \mathrm{~d}$ at Vineyard 1 . The distance from the emitter and sampling depth interaction were related to soil $\mathrm{Br}$ at both vineyards except for the very last sampling period.

Soil $\mathrm{Br}$ remained in a fairly narrow area in Vineyard 1, whereas it was more dispersed in Vineyard 2 (Fig. 2). The soils in both of these vineyards are uniform and the same texture and series. However, as a result of differences in irrigation management, average soil moisture was lower in Vineyard 1 and higher in Vineyard 2 (Davenport et al., 2008). There was a strong positive relationship between soil moisture content and soil $\mathrm{Br}$ concentration $(P<0.01)$. This suggests that $\mathrm{Br}$ movement was related to soil moisture and the irrigation management in each vineyard. To further examine this, spatial distribution maps were made comparing relative soil moisture to relative soil $\mathrm{Br}$ concentration. Because both soil moisture and soil $\mathrm{Br}$ were expressed as percent of the highest value, the relative soil $\mathrm{Br}$ was subtracted from the relative soil moisture and divided into six quantiles. Thus, the dark areas in Figure 3 are where there was high soil $\mathrm{Br}$ and low moisture and the light areas are high moisture and low Br. The similarity between the patterns in Figures 2 and 3 clearly illustrate that $\mathrm{Br}$ moved with the soil moisture and that this was the key to

Table 2. Average soil bromide $(\mathrm{Br})$ concentration $(\mathrm{ppm})$ by depth $(\mathrm{cm})$ and distance from drip emitter $(\mathrm{cm})$ by days after applying $\mathrm{Br}$ as a nutrient tracer in regulated deficit irrigated vineyards in the Yakima Valley, WA. ${ }^{\mathrm{z}}$

\begin{tabular}{|c|c|c|c|c|c|c|c|c|c|c|c|c|}
\hline \multirow[b]{2}{*}{ Vineyard } & \multirow{2}{*}{$\begin{array}{l}\text { Days after } \\
\text { application }\end{array}$} & \multicolumn{5}{|c|}{ Distance from emitter (E) } & \multicolumn{5}{|c|}{ Depth (D) } & \multirow{2}{*}{$\frac{\mathrm{E}^{*} \mathrm{D}}{P}$} \\
\hline & & 0 & 20 & 40 & 60 & $P$ & 0 & 15 & 30 & 45 & $P$ & \\
\hline \multirow[t]{5}{*}{$\overline{1}$} & 1 & $134 \mathrm{a}$ & $103 \mathrm{~b}$ & $5 \mathrm{c}$ & $3 \mathrm{c}$ & $<0.001$ & $102 \mathrm{a}$ & $46 \mathrm{~b}$ & $16 \mathrm{c}$ & $8 \mathrm{c}$ & $<0.001$ & $<0.001$ \\
\hline & 2 & $70 \mathrm{a}$ & $29 \mathrm{~b}$ & $22 b$ & $17 \mathrm{~b}$ & $<0.001$ & $12 \mathrm{~b}$ & $6 \mathrm{~b}$ & $75 \mathrm{a}$ & $64 \mathrm{a}$ & $<0.001$ & $<0.001$ \\
\hline & 7 & $102 \mathrm{a}$ & $103 \mathrm{a}$ & $11 \mathrm{~b}$ & $<1 \mathrm{~b}$ & $<0.001$ & $65 \mathrm{a}$ & $85 \mathrm{a}$ & $12 \mathrm{~b}$ & $7 \mathrm{~b}$ & $<0.001$ & $<0.001$ \\
\hline & 76 & $6 \mathrm{c}$ & $39 \mathrm{a}$ & $23 \mathrm{~b}$ & $3 \mathrm{c}$ & $<0.001$ & 15 & 23 & 22 & 21 & 0.548 & 0.002 \\
\hline & 225 & $8 \mathrm{c}$ & $17 \mathrm{~b}$ & $27 \mathrm{a}$ & $5 \mathrm{c}$ & $<0.001$ & $8 \mathrm{c}$ & $15 \mathrm{~b}$ & $18 \mathrm{ab}$ & $21 \mathrm{a}$ & $<0.001$ & 0.569 \\
\hline \multirow[t]{5}{*}{2} & 1 & $50 \mathrm{a}$ & $36 \mathrm{ab}$ & $23 \mathrm{~b}$ & $1 \mathrm{c}$ & $<0.001$ & $12 \mathrm{~b}$ & $20 \mathrm{~b}$ & $34 \mathrm{a}$ & $24 \mathrm{ab}$ & 0.006 & $<0.001$ \\
\hline & 2 & $19 \mathrm{~b}$ & $45 \mathrm{a}$ & $23 \mathrm{~b}$ & $3 \mathrm{c}$ & $<0.001$ & 21 & 22 & 28 & 22 & 0.914 & 0.028 \\
\hline & 6 & $32 \mathrm{a}$ & $28 \mathrm{a}$ & $21 \mathrm{a}$ & $2 b$ & $<0.001$ & 15 & 16 & 18 & 23 & 0.329 & 0.022 \\
\hline & 76 & $2 b$ & $3 \mathrm{~b}$ & $15 \mathrm{a}$ & $4 \mathrm{~b}$ & $<0.001$ & 10 & 5 & 6 & 6 & 0.145 & 0.091 \\
\hline & 230 & $2 \mathrm{c}$ & $3 \mathrm{c}$ & $7 \mathrm{~b}$ & $10 \mathrm{a}$ & $<0.001$ & 6 & 6 & 5 & 7 & 0.754 & 0.851 \\
\hline
\end{tabular}

${ }^{\mathrm{z}}$ Mean separation by least significant difference $(\alpha=0.05)$ are shown as different letter values when differences were significant (as indicated by $P$ values).

its distribution throughout the vineyard soil profile.

Leaf tissue bromide concentration. Petiole $\mathrm{Br}$ concentration (data not given) differed by vineyard site $(\mathrm{V})$, days after application $(\mathrm{S})$, and the interactive factor $(\mathrm{V} * \mathrm{~S} ; P=$ 0.0004, 0.0001, 0.0004, respectively), whereas blade $\mathrm{Br}$ concentration differed by vineyard $(P=0.024)$. Both petiole and blade $\mathrm{Br}$ were higher at Vineyard $1(45.10,2.55 \mathrm{ppm})$ than Vineyard 2 (8.06, $0.014 \mathrm{ppm})$ and petiole $\mathrm{Br}$ was much higher than leaf Br. This is likely the result of the large amount of blade tissue and differences in organ function between petioles and blades (Keller, 2010). Kung (1990) indicates that plant species widely differ in $\mathrm{Br}$ uptake, which, in combination with a relatively small application rate, may account for why only a small recovery was seen in our study when compared with others (Blumenthal et al., 1999; Kessavalou et al., 1996; Ottman and Pope, 2000).

Regardless of the vineyard, petiole $\mathrm{Br}$ concentration was highest at bloom the next year than at either sampling time during the season or application (data not given). Again, the concentrations were much higher at Vineyard 1 than Vineyard 2 except for the $2 \mathrm{~d}$ after application sampling period. The lower petiole $\mathrm{Br}$ values at Vineyard 2 are likely related to the higher levels of soil moisture in that vineyard, which clearly shows much more movement of $\mathrm{Br}$ deeper in the soil during the first three soil sampling periods (Fig. 2).

To determine if soil $\mathrm{Br}$ at a single or several sampling point was more consistently related to

A

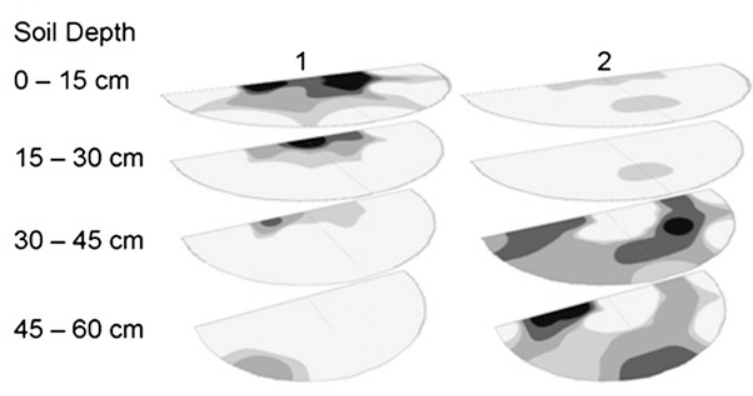

Days after application
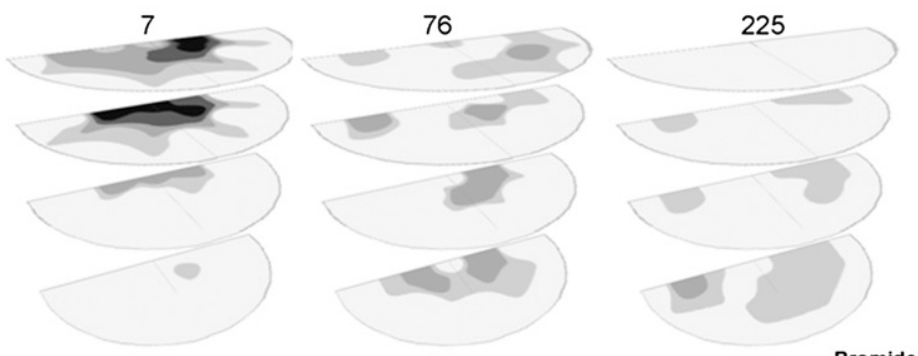

Bromide

$\%$ of highest recovery $\square .5$ $\square \cdot 10$
$\square$
$\square \cdot 25$

B
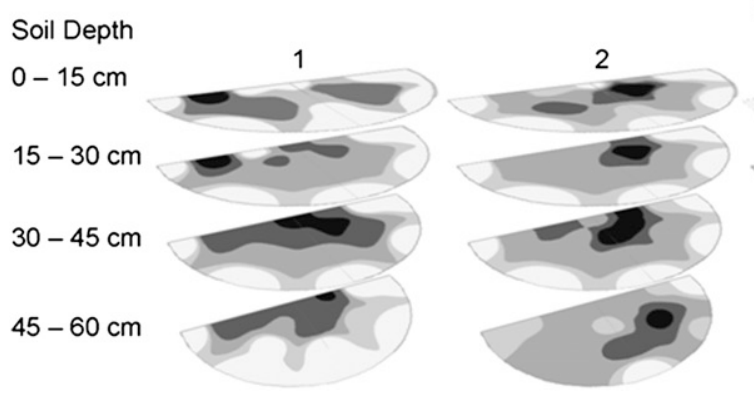

Days after application

6

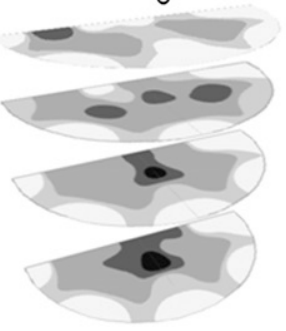

76

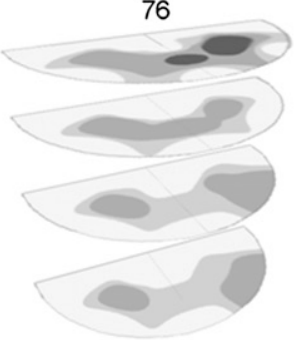

Fig. 2. Soil bromide concentration, expressed as percentage of the highest recovered amount in each vineyard. Data are average of six sampled locations in two 'Merlot' vineyards $(\mathbf{A}=$ Vineyard 1; $\mathbf{B}=$ Vineyard 2) at five different dates after application, which were then extrapolated across the area using ArcGIS (Redlands, CA). First sampling collection was within $24 \mathrm{~h}$ of the application with an irrigation set applied after attaining 650 degree-days $\left(\right.$ base $10{ }^{\circ} \mathrm{C}$ ) with the collections spanning the remainder of the growing season and before budbreak in the next spring. 


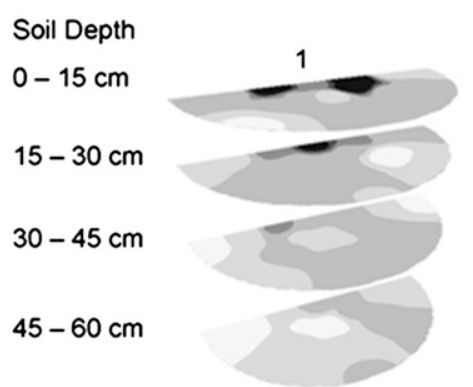

B

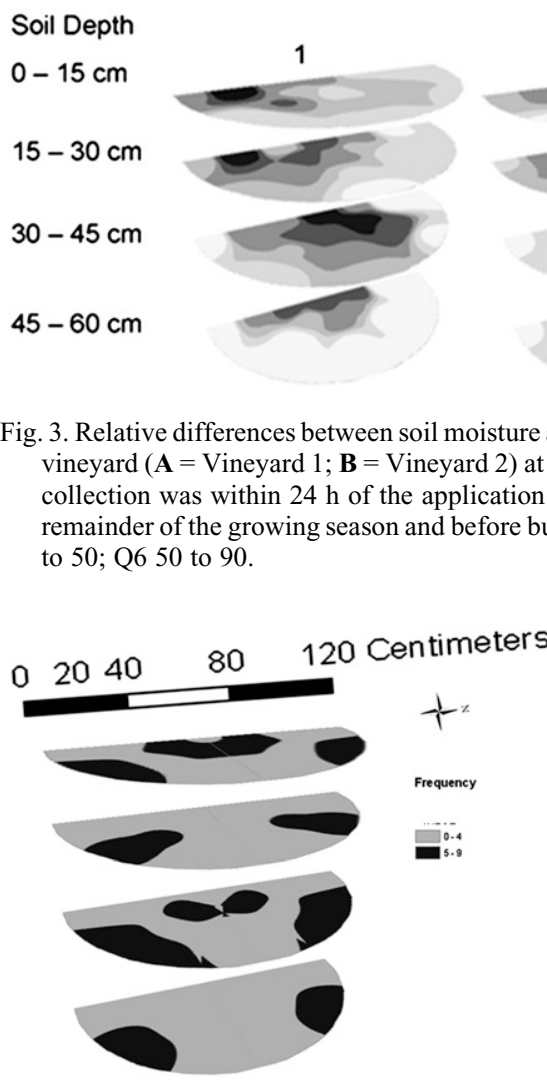

Fig. 4. Frequency of significant relationships (36 relationships possible) between petiole bromide $(\mathrm{Br})$ and soil $\mathrm{Br}$ concentration across all sampling times in a $\mathrm{Br}$ tracer experiment in two deficit-irrigated 'Merlot' vineyards in Yakima County, WA.

petiole $\mathrm{Br}$, regression analysis was performed between petiole and soil $\mathrm{Br}$ concentration for each soil and tissue sampling interval and each soil sampling point. For the purpose of this assessment, the cardinal directions north and south were combined as were northeast and southeast, because, in theory, any differences in these directions should be masked by replication between vines (Fig. 4). In both vineyards, at $20 \mathrm{~cm}$ from the emitter, petiole $\mathrm{Br}$ was most closely related to $\mathrm{Br}$ concentration in the 0 - to $15-\mathrm{cm}$ depth in the east and northeast/southeast direction as well as 30- to $45-\mathrm{cm}$ depth northeast/southeast. At $40 \mathrm{~cm}$

Days after application

2
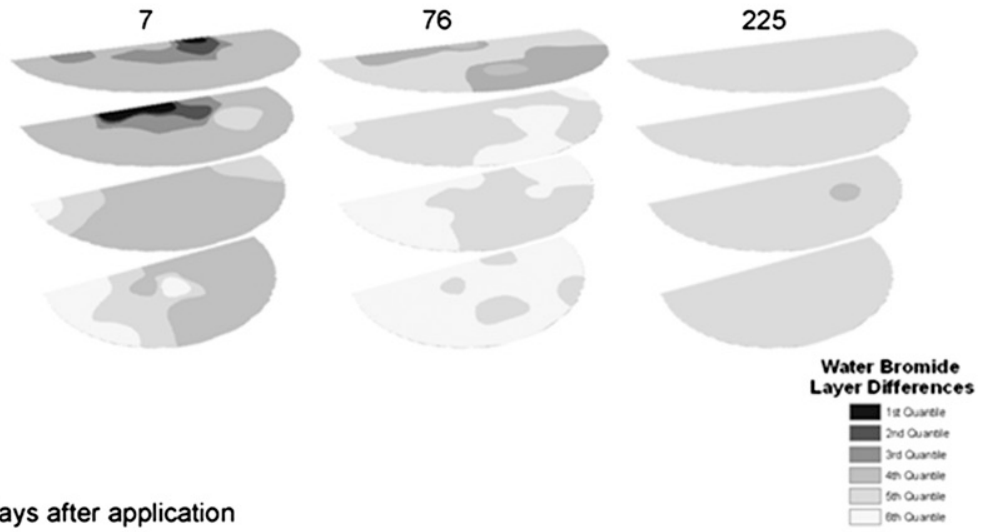

Days after application

2

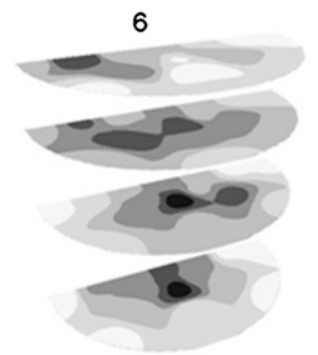

76

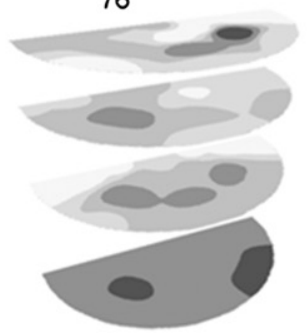

230

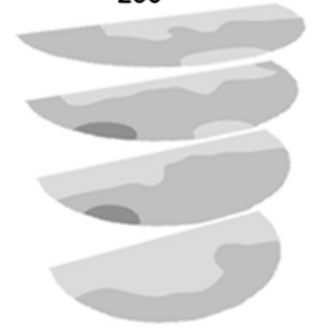

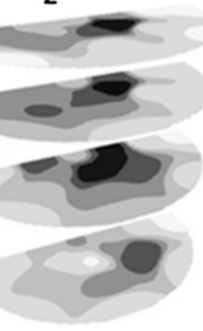

ntration in two 'Merlot'

eyards. Data are average of six sampled locations in two each e different dates after application extrapolated across the area using ArcGIS (Redlands, CA). First sampling with an irrigation set applied after attaining 650 degree-days (base $10^{\circ} \mathrm{C}$ ) with the collections spanning the in the next spring. Quantile values are: Q1 -70 to -31 ; Q2 -30 to $-11 ; \mathrm{Q} 3-10$ to 10; Q4 10 to 30; Q5 30

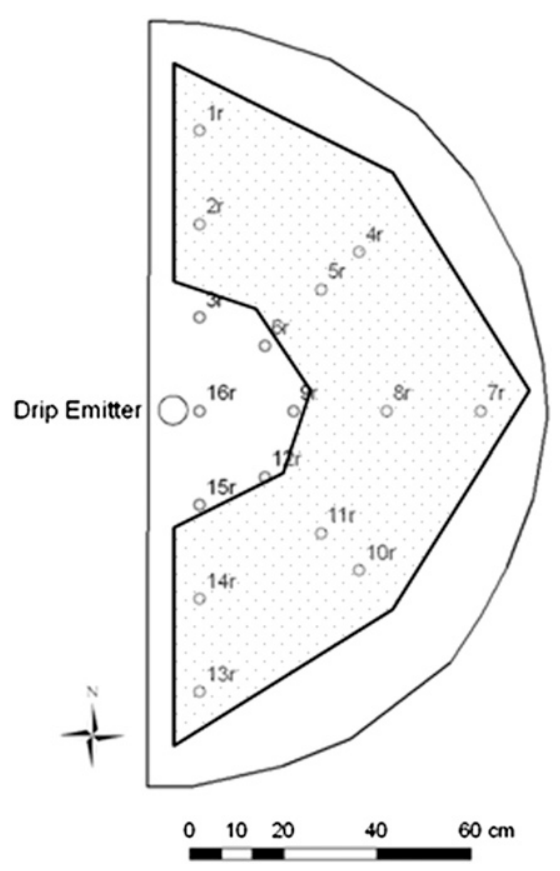

Fig. 5. Diagram of proposed soil sampling zone (stippled area) for regulated deficit, drip-irrigated vineyards based on the bromide tracer experiment in two 'Merlot' vineyards in Yakima County, WA.

distance, Br concentration at the 15 - to $30-\mathrm{cm}$ depth in the northeast/southeast direction was related with petiole $\mathrm{Br}$ concentration, whereas at $60 \mathrm{~cm}$, there were nearly an equal number of significant relationships between tissue and soil $\mathrm{Br}$ concentration at all depths in the northeast/southeast direction. Overall, this suggests that soil sampling for mobile nutrients should be taken from a diagonal position between the vine and the emitter between 20 and $60 \mathrm{~cm}$ from the drip line (Fig. 5). This is consistent with the recommendation for soil moisture sampling found by Davenport et al. (2008). However, further research is needed to determine the relationship between soil $\mathrm{NO}_{3}-\mathrm{N}$ concentration and vine performance.

\section{Literature Cited}

Blumenthal, J.M., M.P. Russelle, and J.F.S. Lamb. 1999. Subsoil nitrate and bromide uptake by contrasting alfalfa entries. Agron. J. 91:269275.

Davenport, J.R., R.G. Stevens, and K.M. Whitley. 2008. Spatial and temporal distribution of soil moisture in drip irrigated vineyards. HortScience 43:229-235.

Elçi, A. and F.J. Molz. 2009. Identification of lateral macropore flow in a forested riparian wetland through numerical simulation of a subsurface tracer experiment. Water Air Soil Pollut. 197:149-164.

Evans, R.G. 1993. Water use of Vitis vinifera grape in Washington. Agr. Water Mgt. 23:109-124.

Evans, R.G., S.E. Spayd, R.L. Wample, M.W. Kroeger, and M.O. Mahan. 1993. Water use of Vitis vinifera grapes in Washington. Agr. Water Mgt. 23:109-124.

Fisher, L.H. and R.W. Healy. 2008. Water movement within the unsaturated zone in four agricultural areas of the United States. J. Environ. Qual. 37:1051-1063. 
Green, C.T., D.A. Stonestrom, B.A. Bekins, K.C. Akstin, and M.S. Schulz. 2005. Percolation and transport in a sandy soil under a natural hydraulic gradient. Water Res. Research. 41:W10414.

Harrison, C.B., W.D. Graham, S.T. Lamb, and A.K. Alva. 1999. Impact of alternative citrus management practices on groundwater nitrate in the Central Florida Ridge. II. Numerical modeling. Trans. ASAE 42:1669-1678.

Izadi, B., B. King, D. Westermann, and I. McCann. 1993. Field scale transport of bromide under variable conditions observed in a furrow-irrigated field. Trans. ASAE 36:1679-1685.

Keller, M. 2010. The science of grapevines: Anatomy and physiology. Elsevier, San Diego, CA.

Keller, M., L.J. Mills, R.L. Wample, and S.E. Spayd. 2004. Crop load management in Concord grapes using different pruning techniques. Amer. J. Enol. Viticult. 55:35-50.

Kessavalou, A., J.W. Doran, W.L. Powers, J.H. Qian, and T.A. Kettler. 1996. Bromide and nitrogen-15 tracers of nitrate leaching under irrigated corn in central Nebraska. J. Environ. Qual. 25:1008-1014.

Kohne, J.M. and H.H. Gerke. 2005. Spatial and temporal dynamics of preferential bromide movement towards a tile drain. Vadose Zone J. 4:79-88.
Kung, K.J.S. 1990. Influence of plant uptake on the performance of bromide tracer. Soil Sci. Soc. Amer. J. 54:975-979.

Logsdon, S.D. 2007. Subsurface lateral transport in glacial till soils. Trans. ASABE. 50:875-883.

Magarian, D.M., M.P. Russelle, J.F.S. Lamb, and J.M. Blumenthal. 1998. Bromide as a tracer for nitrate-N uptake in alfalfa herbage. Agron. J. 90:651-657.

McLeod, M., L.A. Schipper, and M.D. Taylor. 1998. Preferential flow in a well drained and a poorly drained soil under different overhead irrigation regimes. Soil Use Mgt. 14:96-100.

Ottman, M.J. and N.V. Pope. 2000. Nitrogen fertilizer movement in the soil as. influenced by nitrogen rate and timing in irrigated wheat. Soil Sci. Soc. Amer. J. 64:1883-1892.

Patra, A.K. and T.J. Rego. 1995. Movement of bromide as a tracer for nitrate in an Alfisol of the Indian semi-arid tropics under rainfed condition. Fert. Res. 45:111-116.

Rolston, D.E., J.W. Biggar, and H.I. Nighingale. 1991. Temporal persistence of spatial soilwater patterns under trickle irrigation. Irrig. Sci. 12:181-186.

Schnabel, R.R., W.L. Stout, and J.A. Shaffer. 1995. Uptake of a hydrologic tracer (bromide) by ryegrass from well and poorly-drained soils. J. Environ. Qual. 24:888-892.

Schuh, W.M., D.L. Klinkebiel, J.C. Gardner, and R.F. Meyer. 1997. Tracer and nitrate movement to groundwater in the northern Great Plains. J. Environ. Qual. 26:1335-1347.

Seo, Y., J. Lee, W.E. Hart, H.P. Denton, D.C. Yoder, M.E. Essington, and E. Perfect. 2005. Sediment loss and nutrient runoff from three fertilizer application methods. Trans. ASAE 48:2155-2162.

Silvertooth, J.C., J.E. Watson, J.E. Malcuit, and T.A. Doerge. 1992. Bromide and nitrate movement in an irrigated cotton production system. Soil Sci. Soc. Amer. J. 56:548-555.

Stenger, V.A. and I.M. Kolthoff. 1935. Detection and colorimetric estimation of microquantities of bromide. J. Amer. Chem. Soc. 57:831.

Waters, T.D., H.J. Ferguson, R.P. Wight, and D.B. Walsh. 2005. Grapes: Vitis vinifera L. 'Muscat caneli': Insecticide efficacy against leafhoppers in Washington State. Arthropod Management Tests 30:C21.

Woodward, K.B., C.S. Fellows, C.L. Conway, and H.M. Hunter. 2009. Nitrate removal, denitrification and nitrous oxide production in the riparian zone of an ephemeral stream. Soil Biol. Biochem. 41:671-680. 